Article

\title{
Growth-Ring Analysis of Diploknema butyracea Is a Potential Tool for Revealing Indigenous Land Use History in the Lower Himalayan Foothills of Nepal
}

\author{
Md. Qumruzzaman Chowdhury ${ }^{1,2, *(\mathbb{D} \text {, Teeka Ram Bhattarai }}{ }^{3}$, Maaike De Ridder ${ }^{1}$ and \\ Hans Beeckman ${ }^{1}$ D \\ 1 Wood Biology Service, Royal Museum for Central Africa (RMCA), Leuvensesteenweg 13, \\ 3080 Tervuren, Belgium; maaike@wood.be (M.D.R.); hans.beeckman@africamuseum.be (H.B.) \\ 2 Department of Forestry and Environmental Science, Shahjalal University of Science and Technology, \\ Sylhet 3114, Bangladesh \\ 3 Campaigns and Consultations; Education, Livelihood and Social Justice, Post Box 4555 Kathmandu, Nepal; \\ teekab@gmail.com \\ * Correspondence: qumrul@gmail.com
}

Received: 24 December 2019; Accepted: 19 February 2020; Published: 22 February 2020

\begin{abstract}
Slash-and-burn is a farming practice of the indigenous communities in the Himalayan foothills of Nepal. The traditional land-tenure system is based on a customary oral tradition. However, the government's persistent denial of land rights has fueled the indigenous conflicts in the last few decades. Deliverance of scientific evidence-based arguments may underpin the ongoing conflict-resolution dialogues between the authorities and the indigenous communities. Dating growth rings of trees in a slash-and-burn system might help the indigenous people to find evidence of their historic land uses in the mountainous landscape. In this pilot study, we examined the potential of Diploknema butyracea (Roxb.) H. J. Lam growth rings for documenting land use history of Nepalese indigenous farming practices, as this species is being preserved during the slash-and-burn practices. The species is an economically important and ecologically interesting (as it flushes leaves when everything is dry, and sheds leaves while everything is green) deciduous tree species belonging to Sapotaceae family and widely distributed in Sub-Himalayan tracts. Five stem discs were studied which were originated from the Kandrang valley of the Chitwan district, Nepal. For the first time, we revealed distinct growth rings in this species which are marked by fibers with thicker cell walls. Growth-ring anomalies, i.e., wedging and partially missing rings, were also found. Four out of five samples could be crossdated at a marginal level (GLK $\geq 60$ and $t \geq 2.0)$ which is a confirmation of the annual nature of growth rings. One of the samples showed black spots of oxidized wood which are traces of fire, suggesting evidence of slash-and-burn practices in the study area since 1933. This study suggests a strong potential of $D$. butyracea for growth-ring analysis to reconstruct indigenous land use history in Nepal.
\end{abstract}

Keywords: Chepang; slash-and-burn; growth rings; fire traces; dendrochronology; D. butyracea; Nepal

\section{Introduction}

Slash-and-burn is a traditional farming system in the tropics for centuries and it still remains one of the dominant land use practices that provides sustenance for indigenous communities across the world [1]. Securing access to the natural resources and formalizing land rights is essential for their survival [2]. The Chepang is an important indigenous community in Himalayan foothills of Nepal. Their livelihoods depend so far on slash-and-burn farming, which is locally known as Khoriya, in addition to hunting and gathering of wild fruits $[3,4]$. However, the ownership of their 
slash-and-burn lands is based on customary oral tradition. Since 1957, the forest management in Nepal has been brought under government control in Nepal, and the authorities gradually evicted indigenous communities who had no documented ownership of their land [5]. Moreover, modern Nepalese forest related acts, such as the Forest Act of 1993 and Forest Regulations Act of 1996, do not recognize this slash-and-burn system as a formal use of natural resources and the associated land rights of indigenous communities [6]. Consequently, the land tenure system has been gaining a highly debatable socio-political issue in Nepal during the past few decades. Therefore, documenting the slash-and-burn history from appropriate proxies might offer an opportunity for indigenous communities to strengthen their case with scientific evidence-based arguments to resolve the ongoing land use conflicts.

Land use or fire history assessments can be obtained from archived aerial photographs, satellite images or official records [7-10]. The slash-and-burn farming shows a specific pattern of regular fire cycles (starting with slashing and followed with ground fire), which is different from the natural forest fires [11]. There are considerable limitations for obtaining information on the history of indigenous land use in Nepal from the aforementioned sources. For example, the aerial photographs of the slash-and-burn areas in temporal scales are not available [12]. Only since 2000, various sensors, such as MODIS in satellites, have been put into operations which are widely used in the fire studies $[8,13,14]$. It is therefore difficult to acquire previous images of the areas. In addition, the official records of land use history in the area are lacking, which complicates retrieving indigenous land use information. Due to these limitations, the growth rings of old-growth trees surviving in slash-and-burn areas might be a useful proxy for reconstructing fire history and subsequent indigenous land use history [15-18].

Fire induced scars (traces) are a direct evidence of damage to the living cambium of trees creating unique features that are being archived in the wood structure [19-24]. Therefore, time-series based on dated growth rings with associated fire traces are excellent archives to explore land use or fire history [25-29] and growth dynamics of trees [30,31]. To date, relatively few studies in the tropics have focused on fire traces associated with growth rings in tree growth or historical land use studies [32,33], and none have used growth rings in the context of slash-and-burn farming practices. Therefore, dating growth rings and associated fire traces of the slash-and-burn trees might help to develop land-use history of the indigenous communities, in addition to other contexts of growth-ring studies.

Dendrochronological studies in Nepal were started in late 1970s, and the investigations mostly concentrated on a few species, such as Abies spectabilis and Betula utilis at high altitude, focusing mainly on climate issues [34-38]. Only a few studies focused on archeological history [39,40] and on forest ecology, exploring the altitude gradient [41-44]. Apart from anthropogenic disturbances, including slash-and-burn practices, prolonged seasonal drought is an important reason of forest fires in Nepal [10]. Understanding the historical forest fire events or land use changes is an important key to develop a sustainable forest management plan. However, dendrochronological studies related to fire or land use history are completely lacking in these mountainous landscapes, which are yet to be explored.

Diploknema butyracea (Roxb.) H. J. Lam is considered as an important multipurpose tree species belonging to Sapotaceae family and is widely distributed in the Sub-Himalayan tracts [45]. It is a peculiar deciduous species used for fodder as it sheds its leaves in the summer when everything else is green and the tree remains green when everything else is dry in the winter [46-48]. The Chepangs have been managing this species wherever it has grown-in the forests, farmlands, especially in the slash-and-burn areas [49]. Traditionally, the tree is prized for its fruit, both for the sweet aromatic pulp and for the seeds from which edible oil is produced [50,51]. The tree is also an excellent host for bats, birds, and bees. The owner of the tree has traditional rights over hunting the bats and the birds that are foraging or perching on their branches [47]. However, the members of the Sapotaceae family got less attention in dendrochronological applications due to the absence of anatomically distinct growth rings. It is thus essential to check the potential of this species for future dendrochronological applications.

In this pilot study, we examined whether D. butyracea produce annual growth rings. In addition, the existence of fire traces was discussed in relation to slash-and-burn farming practices in the Himalayan foothills of Nepal. 


\section{Materials and Methods}

\subsection{Sample Origin and Study Area}

Five stem discs of D. butyracea were studied from the Tervuren xylarium (RMCA). The collections originated from the Kandrang valley of the Chitwan district, Nepal (Figure 1A). The stem discs have all been collected from the trees surviving in the land used for slash-and-burn agriculture by the Chepang.

The Chepang is one of the 61 indigenous groups recognized by the Nepalese government [6]. They account for $0.25 \%$ of the total population and are living in the rugged terrain of the Mahabharat hills of Central Nepal in the frontier zone between the districts of Makwanpur, Dhading, Chitwan, and Gorkha [52]. The altitudes of the study area vary from $700 \mathrm{~m}$ to $1000 \mathrm{~m}$ above the mean sea level [47]. Historically they have been living in the forests, and their livelihoods mainly depend on collecting wild plant and animal resources [3,53]. In addition, the Chepangs are practicing traditional slash-and-burn agriculture in the forests where D. butyracea trees are mainly protected from slashing for socio-ecological reasons [49].

The climate data of the study site were extracted from the KNMI explorer [54]. The precipitation data of the study area shows a unimodal distribution (Figure 1B). The mean annual temperature of the study area is $27^{\circ} \mathrm{C}$ and annual precipitation is $2200 \mathrm{~mm}$. The precipitation is highly unevenly distributed throughout the year. More than $80 \%$ of the total annual precipitation occurs during the monsoon (June - September).

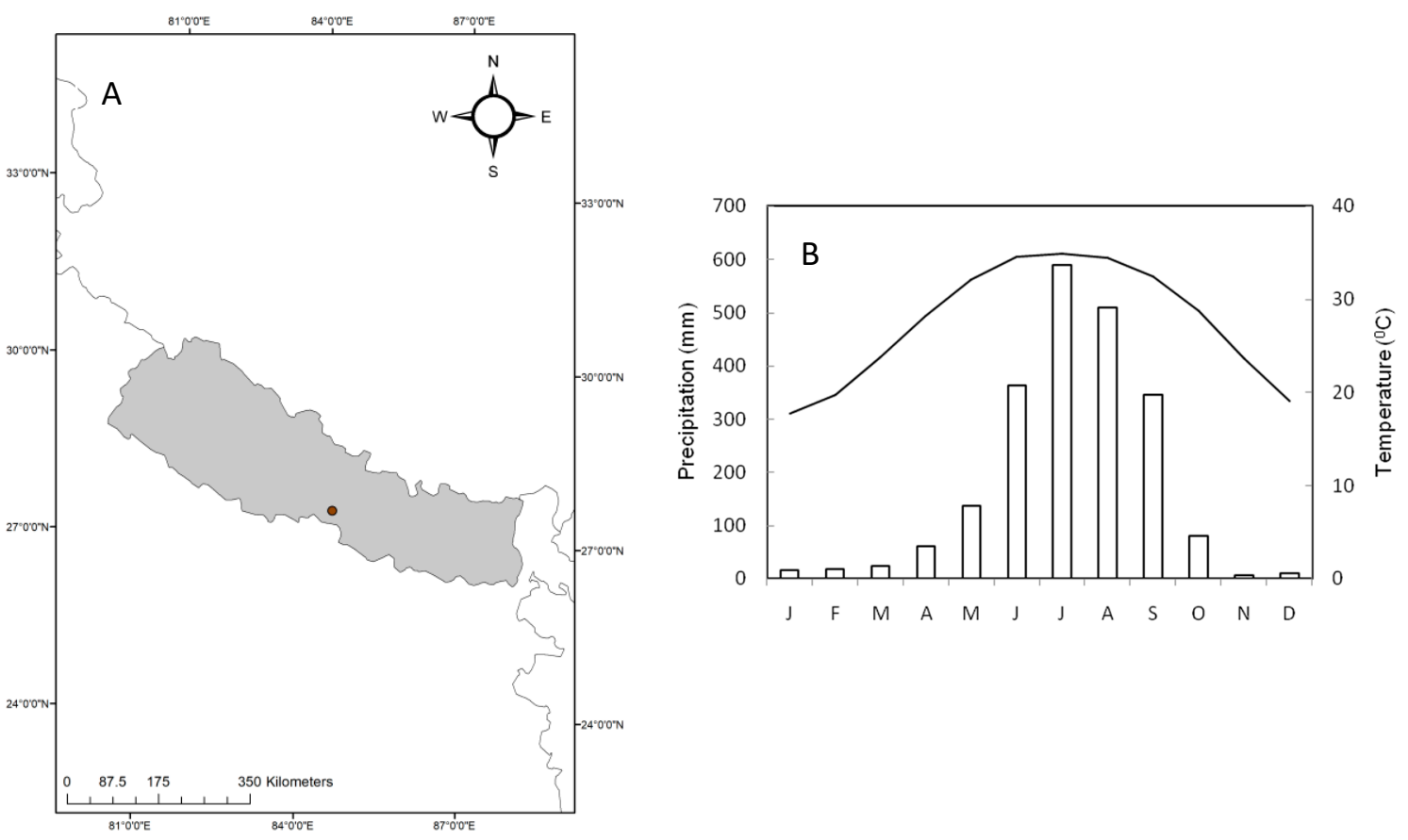

Figure 1. The map of Nepal showing the study area in circle (A); Climate diagram of the study area (B); Vertical bars indicate precipitation and solid line indicates mean temperature. Average data for the period of 1950 to 2000. The map was created using the ArcGIS software (version 10.3, URL: http://www.esri.com/software/arcgis/new). 


\subsection{Sample Preparation and Anatomical Observations}

All stem discs were sanded using a sanding machine with gradually increasing grit from 150 to 1200. The images of the visually distinct growth rings and fire traces were taken with an opto-digital microscope (Keyence VHX-5000, IL, USA). In addition, small blocks of wood both with growth ring and fire traces were prepared for microscopic analysis. Thin sections were prepared with a thickness of $20 \mu \mathrm{m}$ using a sliding microtome (Microm, Fisher Scientific, Walldorf, Germany). The sections were stained with a $0.1 \%$ safranin (Merck KGaA, Darmstadt, Germany) solution in $50 \%$ ethanol and washed in an ethanol series (50,75, 96, and 100\%, 5 min in each concentration) and mounted on slides with Euparal (Carl RothGmbh+ Co. KG., Karlsruhe, Germany). Images of those sections were taken using a microscope equipped with a camera system (Olympus BX60F-3, Tokyo, Japan).

\subsection{Growth-Ring Analysis}

Growth-ring boundaries were marked on the sanded stem discs with a pencil under a stereomicroscope on three radii from pith to bark for checking growth-ring anomalies and ring wedging. The missing rings were identified. After marking, all discs were measured to the nearest 0.01 mm using a stereomicroscope coupled with a Lintab measuring device and TSAP-Win software [55]. The crossdating was done among the radii of each stem disc as a quality check of the measurements. The three growth-ring series were merged into an average growth-ring series per tree. The growth-ring index was calculated by dividing each of the raw growth-ring widths by the value of the fitted spline using the dpIR package in R [56]. Correspondence between different trees was checked by crossdating to ensure that each individual growth ring is assigned to the same calendar year [57]. The crossdating of the growth-ring series was done by visual comparison of the series in addition to two cross dating parameters, such as Student's $t$ [58] and Gleichläufigkeit(GLK) values [59]. The crossdating threshold was set at a $t$ value [58] of $2.0(p<0.05)$ and a GLK of $60 \%$, as it referred the marginal thresholds for other tropical species and limited number of specimens $[60,61]$.

To check the influence of local precipitation on the tree growth, we used the correlation coefficient between annual precipitation and the mean chronology over the common time span from 1950 to 1999.

\section{Results}

\subsection{Anatomy of Growth Ring and Fire Trace}

The wood is diffuse-porous, and the vessels are distributed mostly in groups. Distinct growth rings were observed with the unaided eye on the polished stem discs (Figure 2) and also under the stereomicroscope (Figures $3 \mathrm{~A}$ and $4 \mathrm{~A}$ ). Microtome sections revealed distinct growth rings which are marked by thicker fiber walls (Figure 3B). Growth-ring anomalies, i.e., wedging and partially missing rings were also found. Outer parts of the discs were irregular due to buttress and in the irregular parts many rings merge with the previous one. One of the studied discs (Tw56021) showed multiple fire traces forming small black spots and contained callus tissues (Figures 2 and 4). The anatomical investigation also revealed that wood in the fire induced areas was oxidized compared to the intact wood (Figure 4). 


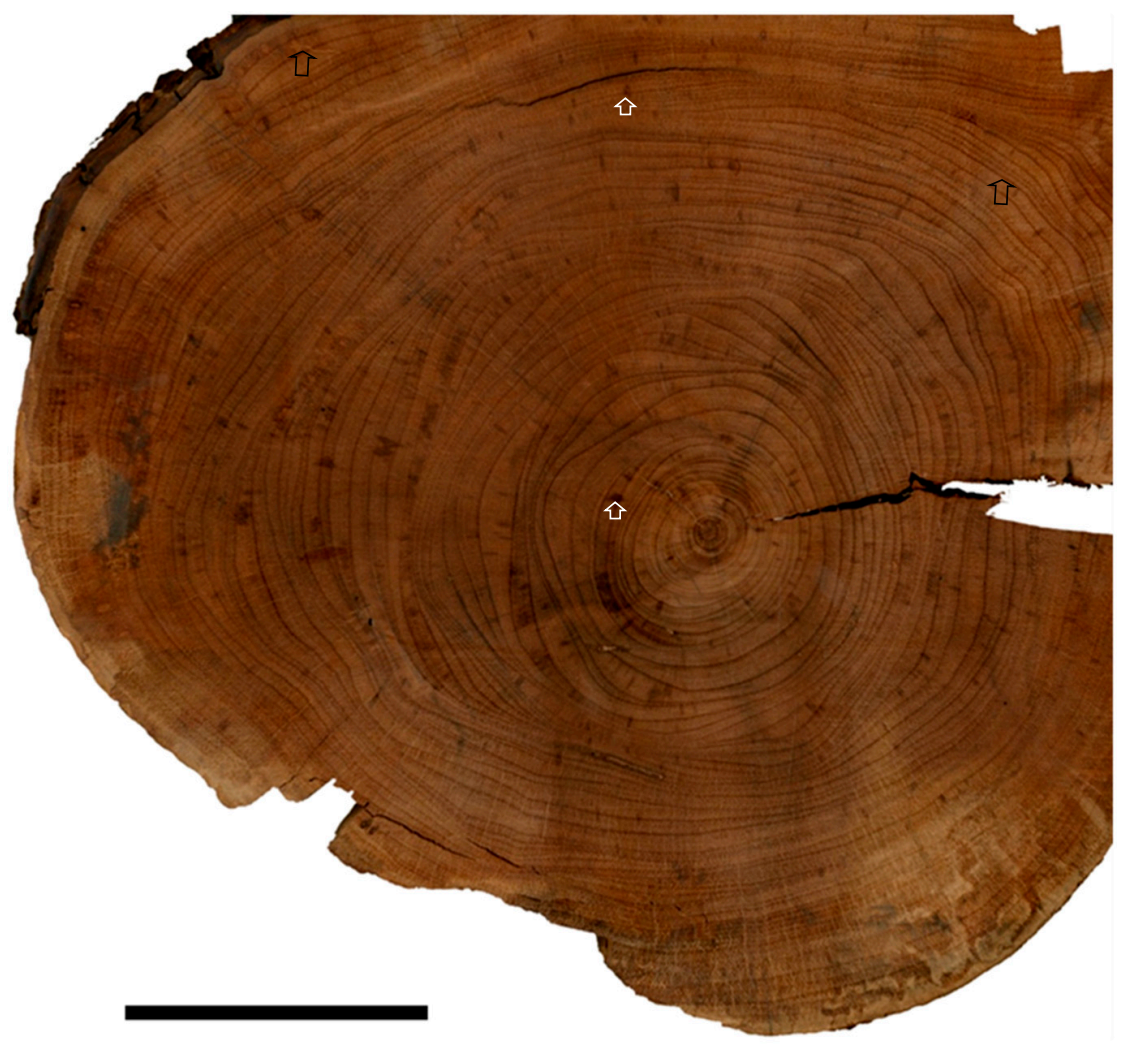

Figure 2. Sanded stem disc of D. butyracea showing growth rings (black arrows indicated) and fire traces (white arrows indicated). Scale bar $=10 \mathrm{~cm}$.
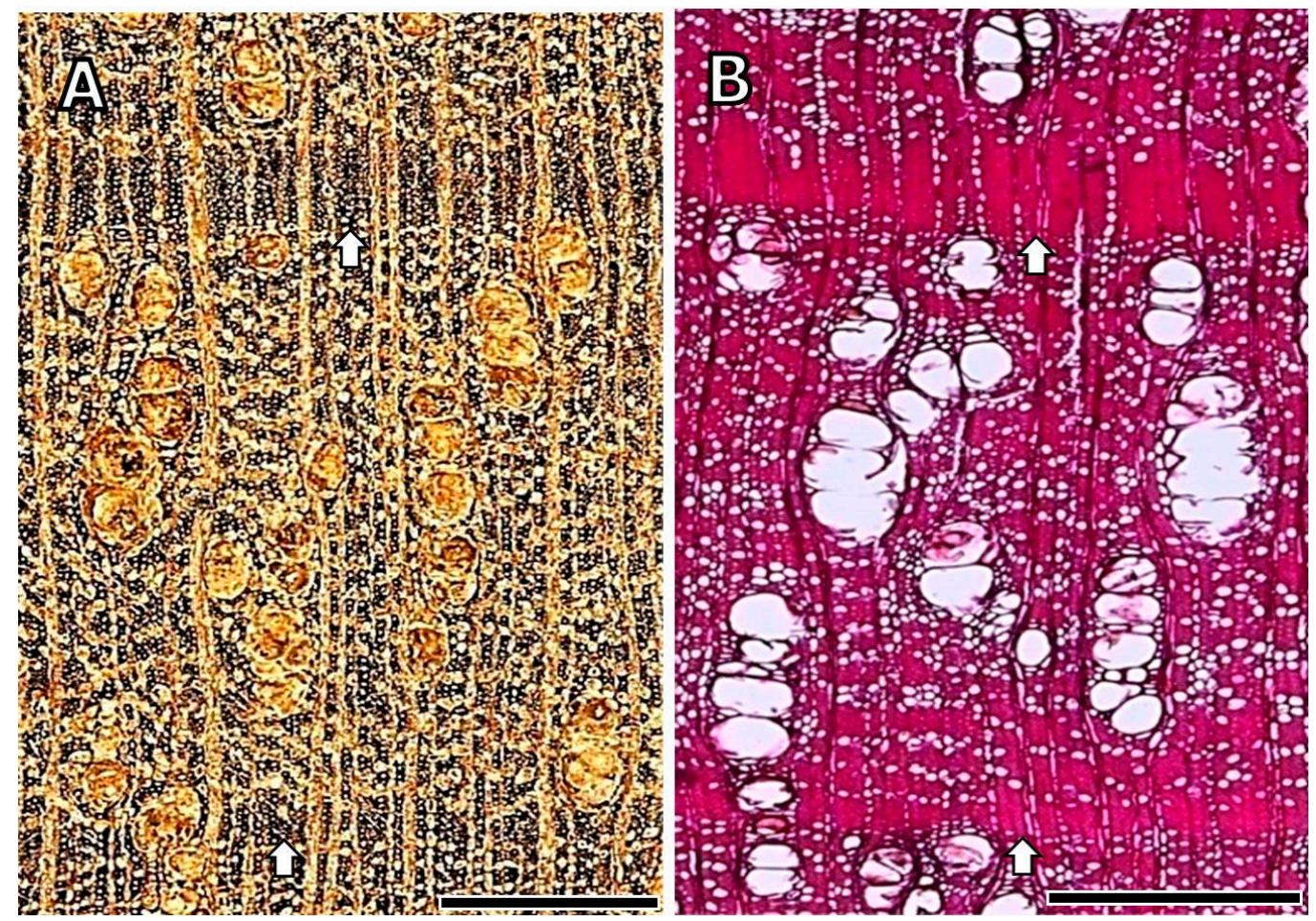

Figure 3. Growth ring structure of D. butyracea; (A) stereomicroscopic image and (B) light micrograph. The white arrow indicates the ring boundary. Scale bars $=500 \mu \mathrm{m}$. 

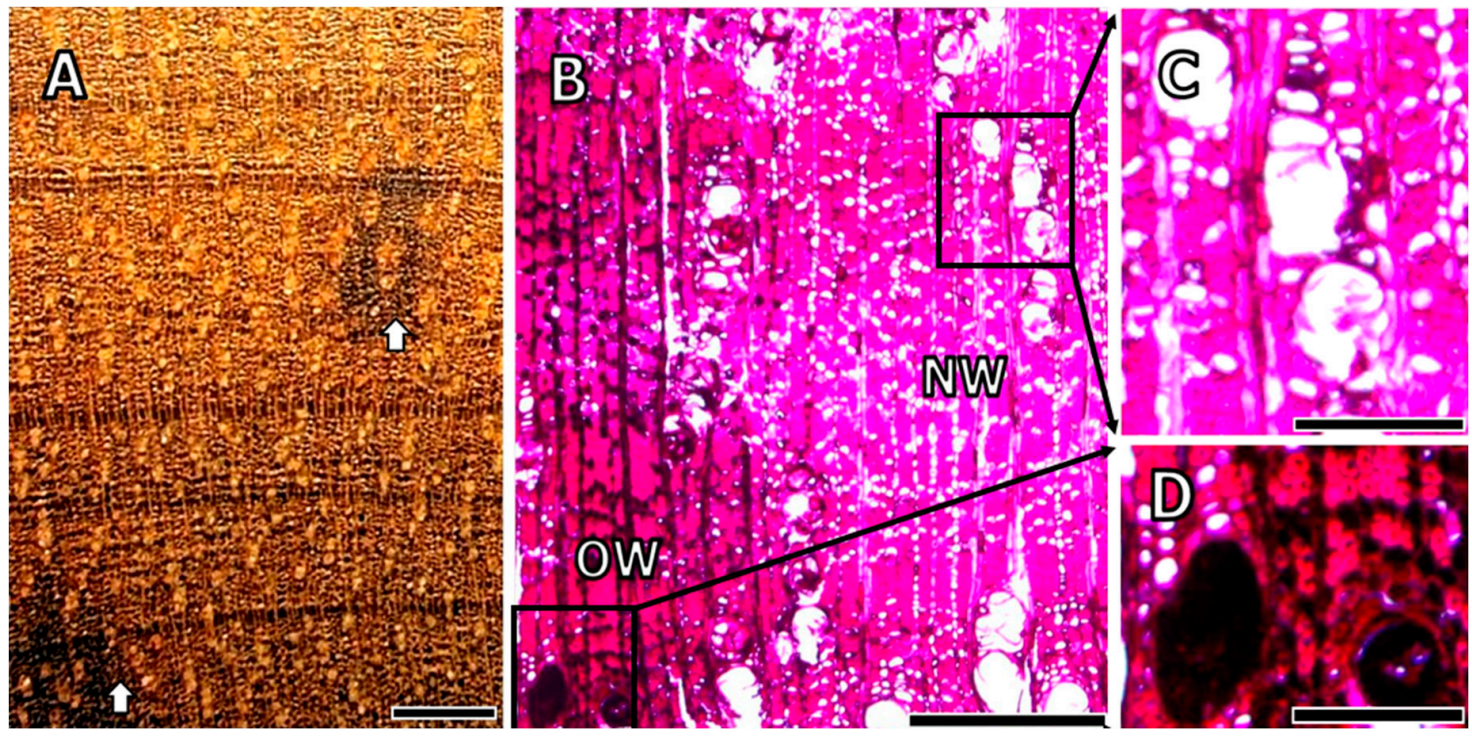

Figure 4. Anatomy of fire trace in D. butyracea wood; (A) fire traces (black spots) on the stem disc (white arrow indicated), stereomicroscopic image; (B) light micrograph showing oxidized and normal wood; (C) non-oxidized wood; and (D) fire induced oxidized wood. Scale bars $=500 \mu \mathrm{m}(\mathbf{A}, \mathbf{B})$ and $200 \mu \mathrm{m}($ C,D). OW, oxidized; NW, non-oxidized wood.

\subsection{Growth-ring Analysis}

Microscopically distinct growth rings of D. butyracea offered an opportunity for growth-ring measurement. Partially missing and wedging rings (rings merge in some parts of the disc) were corrected by checking the whole disc. Crossdating among the individuals was weak but suggested a synchronous growth-ring pattern (Figure S1). For example, four out of five samples crossdated at marginal level ( $G L K \geq 60$ and $t \geq 2.0$ ). The correlation between the average ring width index and annual precipitation was significant $(r=0.38, n=50, p<0.01)$. The age of the studied samples ranged from 51 to 88 years and radial increments varied from 0.25 to $0.36 \mathrm{~cm}_{\text {year }}{ }^{-1}$. The sample with fire traces was considered as a proof of past fire events, and the first fire event was in 1933 and the last event was in1992 (Figure 5). The fire cycle was not constant for the whole study period and varied from 3 to 12 years.

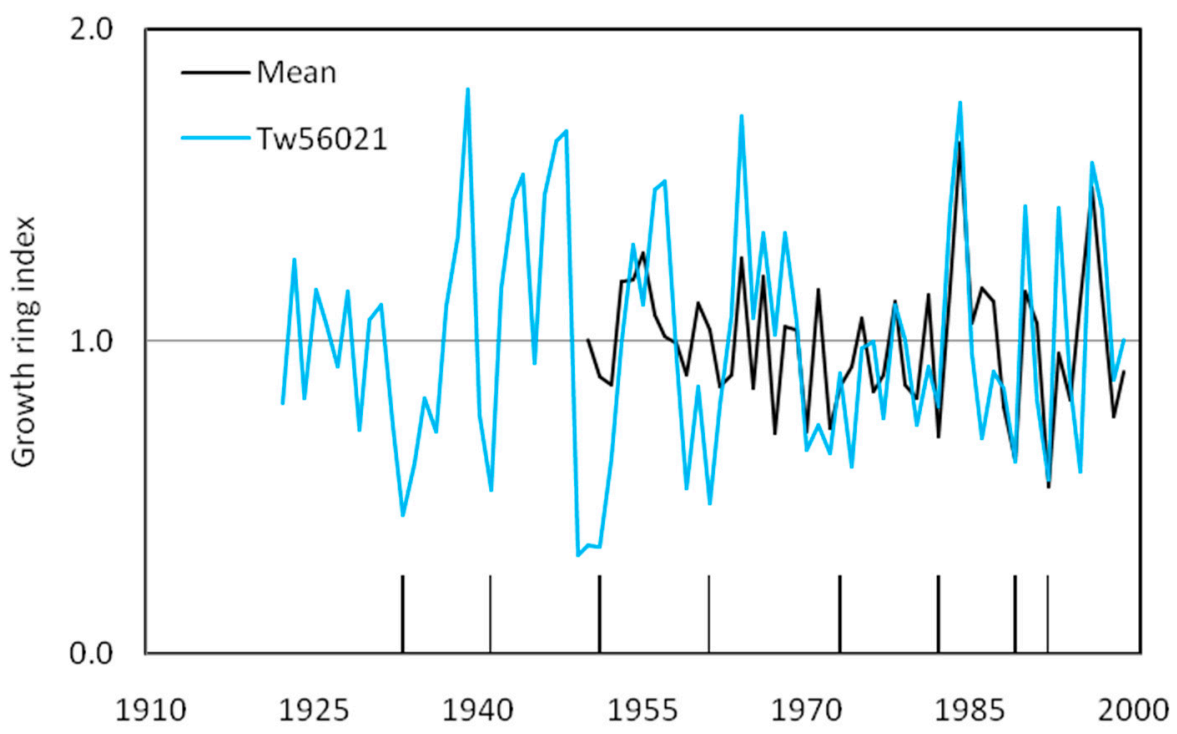

Figure 5. Growth ring index of the fire trace sample of D. butyracea (Tw56021) and mean chronology; vertical bars are fire years. 


\section{Discussion}

\subsection{Growth-Ring Structure and Periodicity}

The studied samples displayed distinct growth rings delimited by fibers with thick cell walls (Figure 3A,B), whereas the growth ring of this species is documented as indistinct like many other species of Sapotaceae [62]. Growth-ring anomalies, for example wedging and partially missing rings, are common that might be associated with phases of low growth rates or eccentric growth occurring in this species, as described for other tropical species [61,63-66]. In addition to visual synchronization, four out of five trees could be statistically crossdated (GLK $\geq 60$ and $t \geq 2.0)$, indicating that their growth showed an annual cycle [60,67-69]. However, the low sample replication did not allow testing for a statistically sound significance of these observations. Besides, this is an interesting deciduous species that sheds its leaves in summer (from late June) and flushes in winter i.e., December to January [46-48]. Cambial activity in many tropical trees is being generally induced by leaf flushing and terminates some time before leaf shedding [70], therefore the growth patterns of this species could be considered as annual because of the deciduous nature of the tree, e.g., [67]. In addition, a correlated growth ring index and annual precipitation is also an indicator for annual nature of the growth rings in this species. The mean ring widths, expressing the growth rates of the trees, showed variability $\left(0.25-0.36 \mathrm{~cm}\right.$ year $\left.{ }^{-1}\right)$ among the trees and the mean annual growth rate amounts to $0.31 \mathrm{~cm} \mathrm{year}^{-1}$.

\subsection{Fire Traces}

The presence of small and multiple traces on in the wood (Figure 2) are typical for low-intensity fires in this species, e.g., [30]. Low-intensity ground fire has been practiced to clear the understory vegetation by the Chepangs for agriculture. In this case, non-lethal heat may damage the cambial zone and xylem tissue beneath the bark and result in traces in the wood, which is also described for other species $[19,23,71,72]$. However, charred tissue was not found, probably because the bark did not completely ignite or combust [20]. The slash-and-burn starts with slashing from December to January, letting the material dry for a few weeks, then it is burned, before sowing the agricultural seeds from March to April [73]. Since the species continues to survive on these sites [47], the fires are most probably of low intensity.

Microtome sections of the fire traces revealed compartmentalization after wounding and the formation of wound induced discolorations (Figure 4B,D). Fire induced compartmentalization might be confining the loss of normal physiological functions to the smallest possible area [74,75]. The discoloration is primarily due to the oxidation of constitutive phenolic compounds [76] where the parenchyma cells might shift their energy-yielding metabolism to the production of phenolic substances which are oxidized in the presence of available oxygen $[77,78]$. However, wound induced oxidation was limited to the time of wounding and did not extend into wood formed after wounding. This might act as a barrier zone that resists the spread of possible infections in sapwood and bark [79,80].

This pilot study indicates that fire history data are archived in the living fire-scarred D. butyracea trees in these mountainous landscapes. These trees are preserved from slashing by the Chepangs for socio-ecological reasons $[47,49]$. For example, leaves of this tree are important fodder, and fruits are used for butter and oil. Moreover, it is an excellent host for bats, birds, and bees where the owner of the tree has rights over hunting the animals and birds that are foraging or perching on their branches. The annual nature of growth rings and the existence of fire traces in the wood indicate the incidence of fires in the study area since 1933, where the last event was in 1992 (Figure 5). It is also noted that after the cropping phase, the land is left fallow up to 12 years and during the fallow period the forest is regenerated [6]. The 12-year cycle is still well known by the Chepangs as 12-year Khoriya (slash-and-burn agriculture). However, due to extreme poverty and decrease of land the fallow periods have been shortened (up to 3 years) [81]. 


\section{Conclusions and Perspectives}

For the first time, we revealed distinct growth rings in D. butyracea with their annual periodicity. The occurrence of small fire traces in wood is due to low-intensity fires. The sample with datable fire traces suggests the existence of fire events in the study site, which probably result from the slash-and-burn farming practices. This pilot study thus suggests the potentials of D. butyracea for understanding the fire history, especially in a context of indigenous land use practices, apart from other possible dendrochronological applications. Future studies would profit from an experimental setup aiming at understanding the timing of growth ring formation and cambial reactions due to heat related damages using cambial markings $[63,65]$ and ecophysiological analyses. Future studies also should consider a larger sample size for the reconstruction of indigenous land use history.

Supplementary Materials: The following are available online at http://www.mdpi.com/1999-4907/11/2/242/s1, Figure S1: Growth ring series of the crossdated samples of D. butyracea.

Author Contributions: M.Q.C. and H.B. have designed the study; T.R.B. has coined the research topic and organized the field work; M.Q.C. and M.D.R. have performed laboratory and data analysis; M.Q.C. has written the manuscript with the support of all co-authors. All authors have read and agreed to the published version of the manuscript.

Funding: This research received no external funding.

Acknowledgments: We thank Debendra Adhikari for collecting the stem discs, and the Chepang communities for sharing their endless knowledge on D. butyracea and their forests. We would also like to acknowledge two anonymous reviewers for their critical and valuable comments on an earlier version of manuscript. The first author was supported by a mobility grant from the Belgian Federal Science Policy office co-funded by the Marie Curie Actions from the European Commission.

Conflicts of Interest: The authors have declared that no competing interests exist.

\section{References}

1. Heinimann, A.; Mertz, O.; Frolking, S.; Egelund, A.C.; Hurni, K.; Sedano, F.; Chini, L.P.; Sahajpal, R.; Hansen, M.; Hurtt, G. A global view of shifting cultivation: Recent, current, and future extent. PLoS ONE 2017, 12, e0184479. [CrossRef]

2. UN. State of World's Indigenous People; Doc.ST/ESA/328; United Nations: NewYork, NY, USA, 2009.

3. Dhakal, S. Anthropological perspective on shifting cultivation: A Case study of Khoriya Cultivation in Arun Valley of Eastern Nepal. Occas. Pap. Sociol. Anthr. 2000, 6, 92-111. [CrossRef]

4. Kerkhoff, E.; Sharma, E. Debating Shifting Cultivation in the Eastern Himalayas: Farmer's Innovations as Lessons for Policy; International Centre for Integrated Mountain Development (ICIMOD): Kathmandu, Nepal, 2006.

5. Piya, L.; Maharjan, K.L.; Joshi, N.P.; Dangol, D.R. Collection and marketing of non-timber forest products by Chepang community in Nepal. J. Agric. Environ. 2011, 12, 10-21. [CrossRef]

6. Sharma, D.P. Understanding the Chepangs and Shifting Cultivation: A Case Study from Rural Village of Central Nepal. Dhaulagiri J. Sociol. Anthr. 2011, 5, 247-262. [CrossRef]

7. Minnich, R.A.; Barbour, M.G.; Burk, J.H.; Sosa-Ramirez, J. California mixed-conifer forests under unmanaged fire regimes in the Sierra San Pedro Martir, Baja California, Mexico. J. Biogeogr. 2000, 27, 105-129. [CrossRef]

8. Oddi, F.J.; Ghermandi, L. Dendroecological potential of shrubs for reconstructing fire history at landscape scale in Mediterranean-type climate grasslands: The case of Fabiana imbricata. Dendrochronologia 2015, 33, 16-24. [CrossRef]

9. Li, P.; Feng, Z. Extent and Area of Swidden in Montane Mainland Southeast Asia: Estimation by Multi-Step Thresholds with Landsat-8 OLI Data. Remote Sens. 2016, 8, 44. [CrossRef]

10. Matin, M.A.; Chitale, V.S.; Murthy, M.S.R.; Uddin, K.; Bajracharya, B.; Pradhan, S. Understanding forest fire patterns and risk in Nepal using remote sensing, geographic information system and historical fire data. Int. J. Wild land Fire 2017, 26, 276-286. [CrossRef]

11. Fujisaka, S.; Hurtado, L.; Uribe, R. A working classification of slash-and-burn agricultural systems. Agrofor. Syst. 1996, 34, 151-169. [CrossRef]

12. Acharya, K.P.; Dangi, R.B.; Acharya, M. Understanding forest degradation in Nepal. Unasylva 2011, $62,238$. Available online: www.fao.org/docrep/015/i2560e/i2560e06.pdf (accessed on 25 March 2019). 
13. Giglio, L. MODIS Collection 4 Active Fire Product User's Guide. Version 2.3; University of Maryland, Department of Geography: College Park, MD, USA, 2007; Available online: http://maps.geog.umd.edu/firms/default.asp (accessed on 2 May 2015).

14. Takahata, C.; Amin, R.; Sarma, P.; Banarjee, G.; Oliver, W.; Fa, J.E. Remotely-sensed active fire data for protected area management: Eight-year patterns in the Manas National Park, India. Environ. Manag. 2010, 45, 414-423. [CrossRef] [PubMed]

15. Fritts, H.C.; Swetnam, T.W. Dendroecology: A tool for evaluating variations in past and present forest environments. Adv. Ecol. Res. 1989, 19, 111-189.

16. Lombardo, K.J.; Swetnam, T.W.; Baisan, C.H.; Borchert, M.I. Using Bigcone Douglas-fir fire scars and tree rings to reconstruct interior Chaparral fire history. Fire Ecol. 2009, 5, 35-56. [CrossRef]

17. Fournier, T.P.; Battipaglia, G.; Brossier, B.; Carcailleta, C. Fire-scars and polymodal age-structure provide evidence of fire-events in an Aleppo pine population in southern France. Dendrochronologia 2013, 31, 159-164. [CrossRef]

18. Sidorova, M.O.; Büntgen, U.; Omurova, G.T.; Kardash, O.V.; Myglan, V.S. First dendro-archaeological evidence of a completely excavated medieval settlement in the extreme north of Western Siberia. Dendrochronologia 2017, 44, 146-152. [CrossRef]

19. McBrdie, J.R. An analysis of tree rings and fire scars to establish fire history. Tree-Ring Bull. 1983, 43, 51-67.

20. Smith, K.T.; Sutherland, E.K. Fire-scar formation and compartmentalization in Oak. Can. J. Res. 1999, 29, 166-171. [CrossRef]

21. Schweingruber, F.H. Tree Rings and Environment: Dendroecology; Paul Haupt Publishers: Bern, Switzerland, 2007.

22. Bigio, E.; Gärtner, H.; Conedera, M. Fire-related features of wood anatomy in a Sweet Chestnut (Castanea sativa) coppice in southern Switzerland. Trees 2012, 24, 643-655. [CrossRef]

23. Smith, A.M.; Sparks, A.M.; Kolden, C.A.; Abatzoglou, J.T.; Talhelm, A.F.; Johnson, D.M.; Boschetti, L.; Lutz, J.A.; Apostol, K.G.; Yedinak, K.M. Towards a new paradigm in fire severity research using dose-response experiments. Int. J. Wild land Fire 2016, 25, 158-166. [CrossRef]

24. Stambaugh, M.C.; Smith, K.T.; Dey, D.C. Fire scar growth and closure rates in white oak (Quercus alba) and the implications for prescribed burning. Ecol. Manag. 2017, 391, 396-403. [CrossRef]

25. Kaye, M.W.; Swetnam, T.W. An assessment of fire, climate, and Apache history in the Sacramen to Mountains, New Mexico. Physic. Geogr. 1999, 20, 305-330. [CrossRef]

26. Taylor, A.H.; Trouet, V.; Skinner, C.N. Climatic influences on fire regimes in montane forests of the southern Cascades. Int. J. Wild land Fire 2008, 17, 60-71. [CrossRef]

27. Conedera, M.; Tinner, W.; Neff, C.; Meurer, M.; Dickens, A.F.; Krebs, P. Reconstructing past fire regimes: Methods, applications, and relevance to fire management and conservation. Quart. Sci. Rev. 2009, 28, 435-456. [CrossRef]

28. Hessel, A.E.; Ariya, U.; Brown, P.; Byambasuren, O.; Green, T.; Jacoby, G.; Sutherland, E.K.; Nachin, B.; Maxwell, R.S.; Pederson, P.; et al. Reconstructing fire history in Central Mongolia from tree-rings. Int. J. Wild land Fire 2012, 81, 86-92. [CrossRef]

29. Harley, G.L.; Baisan, C.H.; Brown, P.M.; Grissino-Mayer, H.D.; Falk, D.A.; Flatley, W.T.; Hessl, A.; Heyerdahl, E.K.; Kaye, M.W.; Lafon, C.W.; et al. Advancing Dendrochronological Studies of Fire in the United States. Fire 2018, 1, 11. [CrossRef]

30. Danzer, S.R.; Baisan, C.H.; Swetnam, T.W. The Influence of Fire and Land-Use History on Stand Dynamics in the Huachuca Mountains of the Southeastern Arizona. In Effects of Fire on Madrean Province Ecosystems: A Symposium; Ffolliott, P.F., DeBano, L.F., Baker, M.B., Gottfried, G.J., Solis-Garza, G., Edminster, C.B., Neary, D.G., Hamre, R.H., Eds.; USDA Forest Service, Rocky Mountain Forest and Range Experiment Station, Fort Collins: Collorado, CO, USA, 1996; pp. 265-270.

31. Harley, G.L.; Grissino-Mayer, H.D.; Horn, S.P. Fire history and forest structure of an endangered subtropical ecosystem in the Florida Keys, USA. Int. J. Wildl Fire 2013, 22, 394-404. [CrossRef]

32. Syampungani, S.; Geledenhuys, C.; Chirwa, P.W. Age and growth rate determination using growth rings of selected miombo woodland species in charcoal and, slash-and-burn re-growth stands in Zambia. J. Ecol. Nat. Environ. 2010, 2, 167-174.

33. Cassell, B.A.; Alvarado, E. Reconstruction of fire history in Mexican tropical pines using tree rings. For. Chronext 2012, 88, 553-555. [CrossRef] 
34. Bhattacharyya, A.; LaMarche, V.C., Jr.; Hughes, M.K. Tree-ring chronologies from Nepal. Tree-Ring Bull. 1992, 52, 59-66.

35. Cook, E.R.; Krusic, P.J.; Jones, P.D. Dendroclimatic signals in long tree-ring chronologies from the Himalayas of Nepal. Int. J. Clim. 2003, 23, 707-732. [CrossRef]

36. Sano, M.; Furuta, F.; Kobayashi, O.; Sweda, T. Temperature variations since the mid- $18^{\text {th }}$ century for western Nepal, as reconstructed from tree-ring width and density of Abies spectabilis. Dendrochronologia 2005, 23, 83-92. [CrossRef]

37. Chhetri, P.K.; Shrestha, K.B. Dendrochronology and climate change study in Nepal: A preview. Banko Janakari 2009, 19, 42-43. [CrossRef]

38. Shrestha, K.B.; Hofgaard, A.; Vandvik, V. Tree-growth response to climatic variability in two climatically contrasting tree line ecotone areas, Central Himalaya, Nepal. Can. J. For. Res. 2015, 45, 1643-1653. [CrossRef]

39. Schmidt, B. Dendrochronological research in south Mustang. Anc. Nepal. 1993, 130-131, $20-25$.

40. Schmidt, B.; Wazny, T.; Malla, K.; Hofs, E.; Khalessi, M. Chronologies for Historical Dating in High Asia/Nepal. In Tree Ring Analysis: Biological, Methodological and Environmental Aspects; Wimmer, R., Vetter, R.E., Eds.; CABI International: Wallingford, UK, 1999; pp. 205-211.

41. Bhuju, D.R.; Carrer, M.; Gaire, N.P.; Soraruf, L.; Riondato, R.; Salerno, F.; Maharjan, S.R. Dendroecological study of high altitude forest at Sagarmatha National Park, Nepal. In Contemporary Research in Sagarmatha (Mt. Everest) Region, Nepal; Jha, P.K., Khanal, I.P., Eds.; Nepal Academy of Science and Technology: Lalitpur, Nepal, 2010; pp. 119-130.

42. Suwal, M.K. Tree Species Line Advance of Abies spectabilis in Manaslu Conservation Area, Nepal Himalaya. Master's Thesis, Central Department of Botany, Tribhuvan University, Kathmandu, Nepal, 2010.

43. Gaire, N.P.; Dhakal, Y.R.; Lekhak, H.C.; Bhuju, D.R.; Shah, S.K. Dynamics of Abies spectabilis in relation to climate change at the tree line ecotone in Langtang National Park, Nepal. J. Sci. Technol. 2011, 12, 220-229.

44. Gaire, N.P.; Koirala, M.; Bhuju, D.R.; Borgaonkar, H.P. Tree line dynamics with climate change at Central Nepal Himalaya. Clim. Past Discuss. 2013, 9, 5941-5976. [CrossRef]

45. Majumdar, K.; Datta, B.K.; Shankar, U. Establishing continuity in distribution of Diploknema butyracea (Roxb.) H. J. Lam in Indian subcontinent. J. Res. Biol. 2012, 2, 660-666.

46. Sundriyal, M.; Sundriyal, R.C. Structure, phenology, fruit yield, and future prospects of some prominent wild edible plant species of the Sikkim Himalaya, India. J. Ethnobiol. 2004, 24, 113-138.

47. Beeckman, H.; Bhattarai, T.R.; Adhihari, D.; Dahal, P.; Mijnsbrugge, K.V. Knowledge Generationon Tropical Forest Products: A Model from Nepal. In Proceedings of the International Symposium on Tropical Forests in a Changing Global Context, Brussels, Belgium, 8-9 November 2004; DeDapper, M., Ed.; UNESCO and Belgian Federal Science Policy Office: Brussels, Belgium, 2005; pp. 293-305.

48. Yadav, R.P.; Bisht, J.K. Agroforestry: Away to conserve MPTs in North Western Himalaya. Res. J. Agric. Sci. 2013, 1, 8-13.

49. Paudel, S.; Wiersum, K.F. Tenure arrangements and management intensity of Butter tree (Diploknema butyracea) in Makawanpur district, Nepal. Int. Rev. 2002, 4, 223-230. [CrossRef]

50. Shakya, M.R. Chepangs and Chiuri-The use of non-timber forest products in Nepal. Intermed. Technol. Food Chain 2000, 26, 3-25.

51. Joshi, N.C.; Chaudhary, A.; Rawat, G.S. Cheura (Diploknema butyracea) as a livelihood option for forest-dweller tribe (Van-Raji) of Pithoragarh, Uttarakhand, India. Int. J. Environ. Rehabilita. Conser. 2018, 9, $134-141$. [CrossRef]

52. Pandit, B.H. Non-timber forest products on shiftingcultivation plots (Khorya): A means of improving livelihood of Chepang Rural Hill Tribe of Nepal. Asia-Pac. J. Rural Dev. 2001, 11, 1-14. [CrossRef]

53. Gurung, G.M. Economic Modernization in a Chepang village in Nepal. Occas. Pap. Sociol. Anthr. 1990, 2, 33-39. [CrossRef]

54. Trouet, V.; Van Oldenborgh, G.J. KNMI Climate Explorer: A web-based research tool for high-resolution paleoclimatology. Tree-Ring Res. 2013, 69, 3-13. [CrossRef]

55. Rinn, F. TSAP-Win ${ }^{T M}$ User Reference; Rinntech: Heidelberg, Germany, 2003.

56. Bunn, A.G. A dendrochronology program library in R (dplR). Dendrochronologia 2008, 26, 115-124. [CrossRef] 
57. Douglass, A.E. Crossdating in dendrochronology. J. For. 1941, 39, 825-831.

58. Baillie, M.G.L.; Pilcher, J.R. Asimpleprogramfortree-ringresearch. Tree-Ring Bull. 1973, 33, 7-14.

59. Eckstein, D.; Bauch, J. Beitragz ur Rationalisierung eines dendrochronologischen Verfahrens und zur Analyse seiner Aussagesicherheit. Forstwiss. Cent. 1969, 88, 230-250. [CrossRef]

60. Trouet, V.; Esper, J.; Beeckman, H. Climate/growth relationships of Brachystegia spiciformis from the miombo woodland in South CentralAfrica. Dendrochronologia 2010, 28, 161-171. [CrossRef]

61. DeRidder, M.; Trouet, V.; denBulcke, J.V.; Hubau, W.; Acker, J.V.; Beeckman, H. A tree-ring based comparison of Terminalia superb climate-growth relationships in West and Central Africa. Trees 2013, 27, 1225-1238. [CrossRef]

62. InsideWood. 2004-Onwards. Published on the Internet. Available online: http://insidewood.lib.ncsu.edu/ search (accessed on 20 November 2019).

63. Trouet, V.; Mukelabai, M.; Verheyden, A.; Beeckman, H. Cambial growth season of brevi-deciduous Brachystegia spiciformis trees from south central Africa restricted to less than four months. PLoS ONE 2012, 7, e47364. [CrossRef] [PubMed]

64. Mbow, C.; Chhin, S.; Sambou, B.; Skole, D. Potential of dendrochronology to assess annual rates of biomass productivity in savanna trees of West Africa. Dendrochronologia 2013, 31, 41-51. [CrossRef]

65. Chowdhury, M.Q.; Kitin, P.; DeRidder, M.; Delvaux, C.; Beeckman, H. Cambial dormancy induced growth rings in Heritiera fomes Buch.-Ham.: A proxy for exploring the dynamics of Sundarbans, Bangladesh. Trees 2015, 30, 227-239. [CrossRef]

66. Gaspard, D.T.; Venegas-González, A.; Beeckman, H.; Randriamalala, J.R.; Tomazello-Filho, M.; DeRidder, M.; Ramananantoandro, T. Tree ring responses to climate variability of xerophytic thickets from South Soalara, Madagascar. Dendrochronologia 2018, 49, 57-67. [CrossRef]

67. Worbes, M. How to measure growth dynamics in tropical trees-A review. IAWA J. 1995, 16, 337-351. [CrossRef]

68. Stahle, D.W. Useful strategies for the development of tropical tree-ring chronologies. IAWA J. 1999, 20, 249-253. [CrossRef]

69. Sass-Klaassen, U.; Couralet, C.; Sahle, Y.; Sterck, F.J. Juniper from Ethiopia contains a large-scale precipitation signal. Int. J. Plant Sci. 2008, 169, 1057-1065. [CrossRef]

70. Borchert, R. Climatic periodicity, phenology, and cambium activity in tropical dry forest trees. IAWA J. 1999, 20, 239-247. [CrossRef]

71. Guyette, R.P.; Cutter, B.E.; Nuzzo, V.A. Tree-ring analysis of fire history of a post oak savanna in the Missouri Ozarks. Nat. Areas J. 1991, 11, 93-99.

72. Gutsell, S.L.; Johnson, E.A. How fire scars are formed: Coupling a disturbance process to its ecological effect. Can. J. Res. 1996, 26, 166-174. [CrossRef]

73. Khadka, R. Transition from Slash-and-Burn (Khoriya) Farming to Permanent Agroforestry in the Middle Hills of Nepal; An Analysis of Cost, Benefits and Farmers Adoption. Master's Dissertation, Norwegian University of Life Sciences, Ås, Norway, 2010.

74. Shigo, A.L. Compartmentalization-A conceptual framework for understanding how trees grow and defend themselves. Annu. Rev. Phytopath. 1984, 22, 189-214. [CrossRef]

75. Blanchette, R.A.; Biggs, A.R. (Eds.) Defense Mechanisms of Woody Plants against Fungi; Springer: Berlin, Germany; New York, NY, USA, 1992.

76. Smith, K.T. Phenolics and Compartmentalization in the Sapwood of Broad-Leaved Trees. In Methods in Plant Biochemistry and Molecular Biology; Dashek, W.V., Ed.; CRC Press: BocaRaton, FL, USA, 1997; pp. 189-198.

77. Smith, K.T. Wounding, compartmentalization, and treatment trade offs. J. Arbor. 1988, 14, $226-229$.

78. Koch, G. Discoloration of Wood in the Living Tree and during Processing. In End User's Needs for Wood Material and Products, Proceedings of the COST E53 Conference, Delft, The Netherlands, 29-30 October 2008; Gard, W.F., van de Kuilen, J.W.G., Eds.; Delft University of Technology: Delft, The Netherlands, 2008; pp. 11-18.

79. Pearce, R.B. Anti microbial defenses in the wood of living trees. New Phytol. 1996, 132, 203-233. [CrossRef] 
80. DeMicco, V.; Zalloni, E.; Balzano, A.; Battipaglia, G. Fire influence on Pinus halepensis: Wood responses close and far from the scars. IAWA J. 2013, 34, 446-458.

81. Kafle, G. An overview of shifting cultivation with reference to Nepal. Int. J. Biodiver. Conserv. 2011, 3, $147-154$. article distributed under the terms and conditions of the Creative Commons Attribution (CC BY) license (http://creativecommons.org/licenses/by/4.0/). 